\title{
電気的物性を利用したフライ油の劣化度の測定
}

\author{
羽倉義雄 ${ }^{8}$, 佐々木芳浩, 鈴木寛一 \\ 広島大学大学院生物圏科学研究科
}

\section{Measurement of Deterioration of Frying Oil Using Electrical Properties}

\author{
Yoshio Hagura $^{\S}$, Yoshihiro Sasaki and Kanichi Suzuki \\ Graduate School of Biosphere Science, Hiroshima University, \\ 1-4-4 Kagamiyama, Higashi-Hiroshima, Hiroshima 739-8528
}

\begin{abstract}
In this study, the relationship between the electrical properties of frying oil (relative dielectric constant and conductance) and its deterioration indicators (acid value, amounts of polymerized triacylglycerols and chromaticity) were examined, focusing on the changes in electrical properties that accompany deterioration. The samples of frying oil used in this experiment were collected from fried food processing sites (school, hospital and factory feeding centers) and were collected at closing time every day for a maximum of ten days. An LCR meter was used for measurement of the electrical properties of the oil, and the relationships between the deterioration indicators and the electrical properties of samples used for various lengths of time were examined. It was found that more deterioration in the frying oil resulted in a greater relative dielectric constant and conductance. In particular, a clear correlation between the degree of deterioration and the conductance of the frying oil was observed. In addition, the obtained gradient $(\mathrm{dG} / \mathrm{dT})$ of conductance temperature dependence of frying oil used in this experiment showed a strong correlation with all deterioration indicators (acid value, amounts of polymerized triacylglycerols and chromaticity). From the above results, it is clear that the degree of deterioration of frying oil can easily be determined based on the conductance temperature dependence.

(Received Jan. 4, 2006 ; Accepted Jun. 10, 2006)
\end{abstract}

揚げ物は食用油脂を用いる調理法の一つで, 焼く, 蒸す, 煮るなどの調理法と並んで日常広く用いられている1). フ ライ食品は惣菜などの身近な食品として, 弁当工場や給食 センターなどで大量に製造されている. フライ油の品質管 理において最む大きな問題は，フライ工程中に起こるフラ イ油の劣化現象である. フライ油の劣化現象は, 外見上は あとより食品の安全性の面からあ望ましくない变化であ る. フライ油の品質管理がフライ食品の品質に直結するた め，フライ油の使用限界の見極めという問題は，フライ食 品を製造する場合に非常に重要な問題である2).

フライ油の劣化は, 熱酸化, 熱重合, 熱分解, 加水分解 などの反応が複合的に起こる現象である。フライ油の劣化 度の定量に関しては様々な研究が報告されている3 〜5). 食 品の製造現場では, 劣化指標として酸価, カルボニル価, 重合物量, 極性化合物量などが用いられているが, 国や地 域により用いられる指標は異なっている。例えば日本で は, フライ現場における品質管理において, 酸価 2.5 , カル ボニル価 50 , 発煙点 $170^{\circ} \mathrm{C}$ という指針が制定されている ${ }^{6)}$ が，現状では，歴史的に長く利用されている酸価が主要な

干739-8528 広島県東広島市鏡山 1-4-4

$\S$ 連絡先 (Corresponding author), hagura@hiroshima-u.ac.jp
管理指標となっている．また，これに合わせて酸価の測定 が比較的容易に行える簡易試験紙屯販売されている7 ${ }^{7}$.

一方，ヨーロッパでは極性化合物量もしくは重合物量が フライ油の管理指標となっている. フライ油が劣化して生 じる種々の物質（分解生成物, 重合物, 遊離脂肪酸など） は全て極性を持っており, トリグリセライド以外の形状と なった全ての物質の総量を極性化合物量と定義している. そのため，極性化合物量は劣化生成物全体を表す指標にな るとヨーロッパでは考えられている。同様の理由で, 酸価 やカルボニル価などは，劣化生成物の一部を測定している にすぎないため, 複雑なフライ油の劣化現象を反映する指 標としては適さないとも考えられている.

さらに，フライ油の劣化度を判断する際には，指標のい ずれかを単独に測定するだけではフライ油の劣化の実情と は異なった判断を下す可能性があることを指摘する意見む ある。この意見では，一般的に用いられている酸価に加え て，極性化合物量や他の劣化指標を組み合わせてフライ油 の劣化度を判断することを勧めている8).

現在使用されている種々の劣化指標の測定方法は, 煩雑 で測定に時間や手間を要するなどの問題点がある.ところ で近年, 食品の品質やその特性を評価する方法として, 対 
象物を非破壊的に評価する技術が注目されている。非破壊 法は, 使うエネルギーの種類によって, 電磁気学的方法, 光 学的方法, 力学的方法, 放射線的方法などに分類される. そ の中で，電磁気学的方法は，電気的あるいは磁気的特性か ら対象物の品質, 特性などを計測する方法である. 特に, 比 誘電率 (静電容量) やコンダクタンスの測定は，(1) 比較的 安価な装置で測定が可能であること，(2)測定方法が簡単で あること，(3) 電極板形状の自由度が高いことなどの理由か ら, 食品の製造現場への応用の可能性屯高いと考えられる.

本研究では, 劣化に伴うフライ油の電気的物性の变化に 注目し, 電気的物性（比誘電率，コンダクタンス）と複数 の劣化指標（酸価, 重合物量, 色度）との関係について検 討を行った。

\section{実 験 方 法}

\section{1. 実験試料}

フライ食品の製造現場で採取したフライ油を実験試料と した，採取先は，広島市内の学校給食センター 1 ケ所（略 号: S1), 病院給食センター1 ケ所 (H1), 工場給食セン ター 2 ケ所（F1，F2）とした。採取先の選定に当たっては, 同一メーカーの同一ブランドの大豆白絞油を使用している 給食センターを選択した。各採取先では，新油（使用 0 日 目）および毎日の終業時のフライ油を最長 10 日間に亘っ て採取した。採取の最終日は，その給食センターが定めた フライ油の廃棄日に対応する。本研究では，油の採取場所 を S1，H1，F1，F2 と表示し，使用日数を数字で表すこと にした。例えば，学校給食センターで採取した新油を S1-0 と表示し，1 日使用後の油を S1-1，4 日使用後の油を S1-4 と表した。また，採取先の給食センターでは，始業時に前 日の操業で減少した油に相当する量の新油をフライヤー内 に注ぎ足しているため，劣化指標の変化には新油の注ぎ足 しによる変化も含まれている。

採取したフライ油の劣化指標として, 酸価, 重合物量, 色度を測定した。酸価は，日本で最むよく使用されている 指標で, 主に加水分解によって生じる遊離脂肪酸の量を示 す指標である，重合物量は，熱重合により生成した重合物 の量を示す指標である。 また色度は, 劣化に伴う油脂の着 色の程度を示す指標である. 酸価は基準油脂分析試験法 （2.3.1-1996）に基づいて測定した。色度は基準油脂分析試 験法（2.2.1.1-1996）に基づき，ロビボンド法で測定した。 重合物量は基準油脂分析試験法（暫 16-2005）に基づき，ゲ ル浸透クロマトグラフ法で測定した。酸価，重合物量，色 度の測定は日清オイリオグループ(株) に依頼した. 使用し たフライ油の使用日数と劣化度（酸価，重合物量，色度） を表 1 に示す.

\section{2. 電気的物性測定装置}

フライ油の電気的物性の測定には，自作の平行平板電極 に LCR メータ（HIOKI 社製，3532-50 LCR HITESTER）
表 1 実験に使用フライ油の使用日数と劣化指標との関係

\begin{tabular}{lccccc}
\hline \hline フライ油の種類 & 使用日数 & No. & 酸価 & 重合物量 & 色度 \\
\hline 学校給食 & 0 & S1-0 & 0.04 & 0.6 & 1.6 \\
(S1) & 1 & S1-1 & 0.82 & 2.8 & 24.3 \\
& 2 & S1-2 & 1.34 & 3.9 & 41.0 \\
& 3 & S1-3 & 2.24 & 5.0 & 75.2 \\
& 4 & S1-4 & 2.87 & 5.4 & 89.0 \\
\hline 病院給食 & 0 & H1-0 & 0.04 & 0.8 & 1.5 \\
(H1) & 1 & H1-1 & 0.06 & 1.2 & 6.7 \\
& 2 & H1-2 & 0.07 & 1.5 & 9.0 \\
& 3 & H1-3 & 0.23 & 2.7 & 22.0 \\
\hline 工場給食 & 0 & F1-0 & 0.04 & 0.9 & 1.5 \\
(F1) & 1 & F1-1 & 0.18 & 2.4 & 11.0 \\
& 2 & F1-2 & 0.19 & 2.3 & 10.8 \\
& 3 & F1-3 & 0.17 & 2.3 & 10.7 \\
& 4 & F1-4 & 0.20 & 2.4 & 11.1 \\
& 5 & F1-5 & 0.21 & 2.3 & 11.1 \\
& 10 & F1-10 & 3.09 & 10.8 & 200.0 \\
\hline 工場給食 & 0 & F2-0 & 0.04 & 0.7 & 1.4 \\
(F2) & 1 & F2-1 & 0.23 & 2.7 & 11.5 \\
& 2 & F2-2 & 0.23 & 2.8 & 未測定 \\
& 3 & F2-3 & 0.22 & 2.6 & 11.6 \\
& 4 & F2-4 & 0.22 & 2.6 & 未測定 \\
& 5 & F2-5 & 0.28 & 3.0 & 15.2 \\
& 6 & F2-6 & 0.81 & 4.7 & 未測定 \\
& 7 & F2-7 & 1.40 & 6.5 & 113.0 \\
& & F2-8 & 2.38 & 10.3 & 180.0 \\
\hline
\end{tabular}

を接続した電気的物性測定装置を使用した。装置の概略を 図 1 に示す. 平行平板電極 (ステンレス製, 縦 $100 \mathrm{~mm} \times$ 横 $60 \mathrm{~mm} \times$ 厚さ $2 \mathrm{~mm}$, 電極板間距離 $4 \mathrm{~mm}$ ） をステンレス製 ビーカー（2L 容）内に設置した。このステンレス製ビー カーは，アースに接続されており，ガード電極としての機 能む有する．まず始めに，平行平板電極が空の状態で静電 容量 $\left(\mathrm{C}_{0}\right)$ を室温（約 $\left.20^{\circ} \mathrm{C}\right)$ で測定した. 次に，ステンレス 製のビーカー（2L 容）に常温のフライ油を $1.4 \mathrm{~L}$ 注ぎ，こ のビーカーを加熱し, 油の温度を $140^{\circ} \mathrm{C}, 160^{\circ} \mathrm{C}, 180^{\circ} \mathrm{C}$, $200^{\circ} \mathrm{C}$ に調節し, 低温加 ら順に電気的物性（静電容量 $\mathrm{C}, コ$ ンダクタンス $G$ ）の測定を行った。 各設定温度において油 の温度が一定になり，測定值が安定したことを確認した 後, 1 分間間隔で 10 回測定を行い, 10 回の平均值を測定值 として採用した。

\section{3. 測定周波数の決定}

予備実験として，使用日数（劣化度）が異なるフライ油 を用い，静電容量およびコンダクタンスの周波数依存性 （50 Hz〜1 MHz の範囲）を測定した。その結果，10 kHz〜 $1 \mathrm{MHz}$ の測定範囲において，緩和現象（測定周波数の増加 に伴う静電容量の減少およびコンダクタンスの増加）が認 められた. 一方, $50 \mathrm{~Hz} \sim 10 \mathrm{kHz}$ の測定範囲では, 静電容量 およびコンダクタンスは周波数依存性を示さず，使用日数 


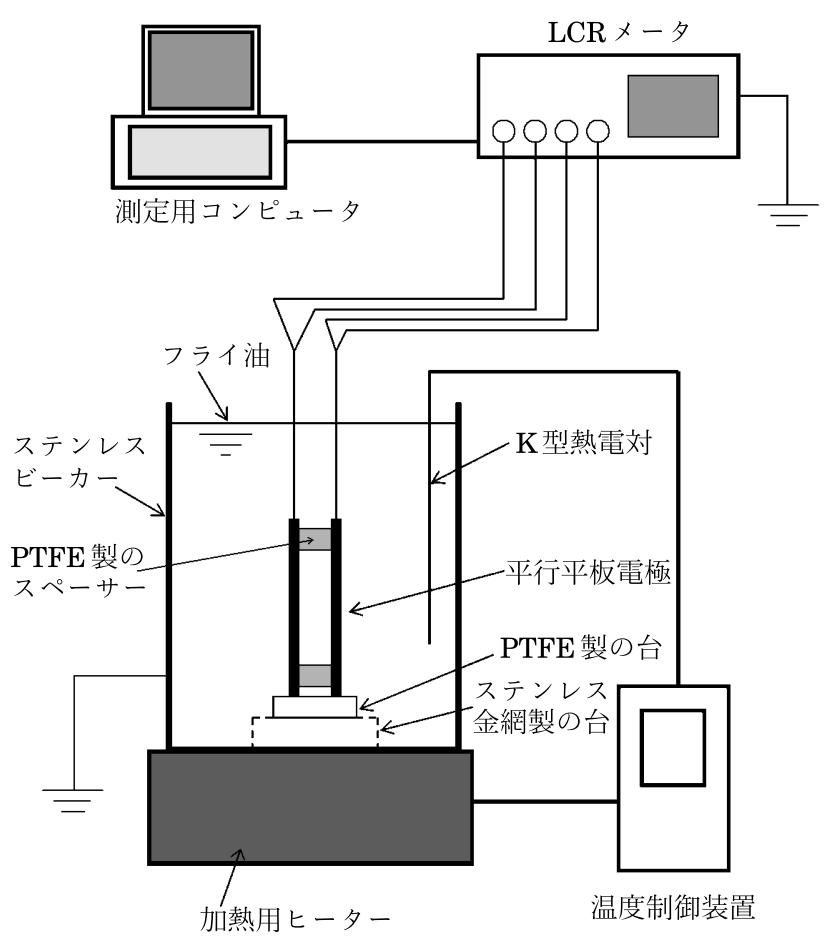

図 1 平行平板電極を使用した電気的物性測定装置

が多いフライ油ほどコンダクタンスの絶対值が増加する比 較的単純な变化を示した。 そこで本研究では, 緩和現象が 現れない $50 \mathrm{~Hz} \sim 10 \mathrm{kHz}$ の測定範囲で電気的物性の測定が 容易になると考えた. 加えて, 可能な限り簡単な方法でフ ライ油の劣化度を捕捉する方法の検討も重要な課題である と考えた. そこで, $50 \mathrm{~Hz} \sim 10 \mathrm{kHz}$ の測定範囲において, 単 一の周波数を選択し $(1 \mathrm{kHz})$, 電気的物性の変化からフラ イ油の劣化度の測定を試みることにした。

\section{4. 比誘電率の算出方法}

平行平板電極間が空の状態および油で満たされた状態の 静電容量をそれぞれ, 空気の静電容量 $\left(\mathrm{C}_{0}\right)$ および油の静 電容量（C）とし，(1)式を用いて比誘電率を算出した ${ }^{9)}$.

$$
\varepsilon(\text { 比誘電率 })=\frac{\mathrm{C}(\text { 油の静電容量 })}{\mathrm{C}_{0}(\text { 空気の静電容量 })}
$$

\section{5. コンダクタンスと導電率, 抵抗率との関係}

平行平板電極では，コンダクタンス $\mathrm{G}[\mathrm{S}$ (ジーメンス, $\mathrm{S}=1 / \Omega)]$ は電極板面積 $\mathrm{A}\left[\mathrm{m}^{2}\right]$ に比例し, 電極板間隔 $\mathrm{d}$ $[\mathrm{m}]$ に反比例する. そして，この時の比例定数が導電率 $\kappa$ $[\mathrm{S} / \mathrm{m}]$ である ${ }^{9)}$. さらに, この導電率 $\kappa$ の逆数 $(\rho=1 / \kappa)$ を抵抗率 $\rho$ という。これらの関係は (2) 式のように表すこ とができる.

$$
\mathrm{G}=\kappa \frac{\mathrm{A}}{\mathrm{d}}=\frac{1 \mathrm{~A}}{\rho \mathrm{d}}
$$

コンダクタンスと導電率，抵抗率との関係は $(2)$ 式より,

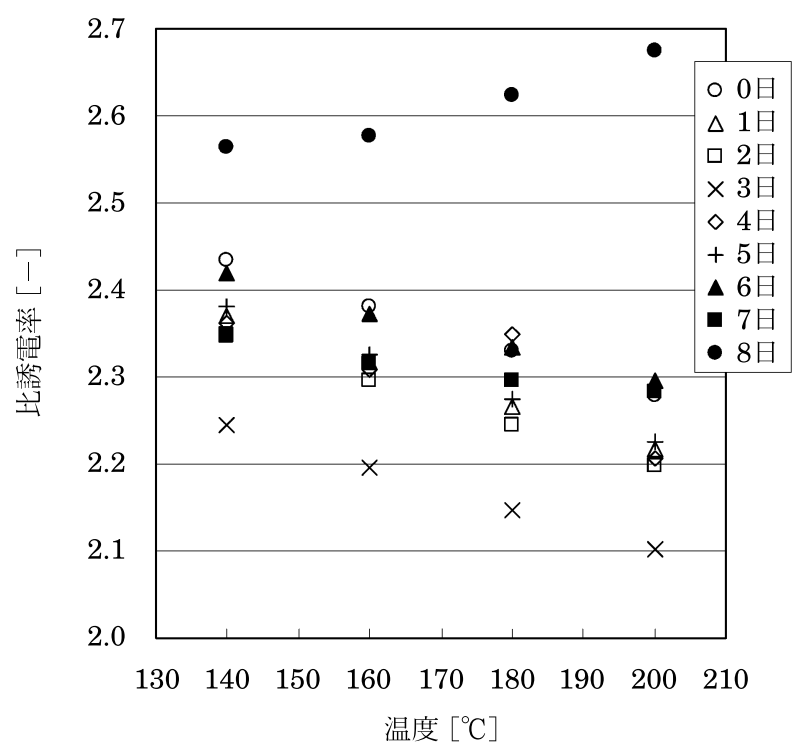

図 2 工場給食フライ油 F2 の測定温度と比誘電率との関係

次のように考えることができる，すなわち，電極板面積 $\mathrm{A}$ と電極板間隔 $\mathrm{d}$ が一定の場合, 試料の導電率 $\kappa$ が増加する と, 測定されるコンダクタンスも増加する. また, 試料の 抵抗率 $\rho$ が減少した場合にあ, 測定されるコンダクタンス は増加する。

\section{実験結果および考察}

\section{1. 使用日数が異なるフライ油の比誘電率およびコンダ} クタンス

使用日数が異なるフライ油の比誘電率を $140,160,180$, $200^{\circ} \mathrm{C}$ で測定した。一例として工場給食で使用したフライ 油（F2）の測定結果を図 2 に示した。使用日数と比誘電率 との間には明確な関連性は認められなかった。同一使用日 数のフライ油では, 測定温度の上昇に伴い比誘電率は概ね 減少する傾向を示した. しかし, 一部のフライ油（例えば, F2-8）では，温度上昇に伴い比誘電率が増加する傾向を示 した. 比誘電率の絶対值や温度依存性の傾きが，使用日数 で異なる理由については，その原因を明確にすることはで きなかった。 この点については，今後さらに検討する必要 がある。

使用日数が異なるフライ油のコンダクタンスを 140 , 160, $180,200^{\circ} \mathrm{C}$ で測定した。一例として工場給食で使用し たフライ油（F2）の測定結果を図 3 に示した。使用日数の 増加に伴いコンダクタンスは増加する傾向を示した。この 傾向は，測定した全てのフライ油において同様であった。 同一使用日数のフライ油では, 測定温度の上昇に伴いコン ダクタンスは直線的に変化した。 また，フライ油の使用日 数が増加するに従い直線の傾きが大きくなる傾向が見られ た。これは，新しい油ほど，コンダクタンスの温度依存性 が小さく，フライ油の使用日数が増加するほどコンダクタ 


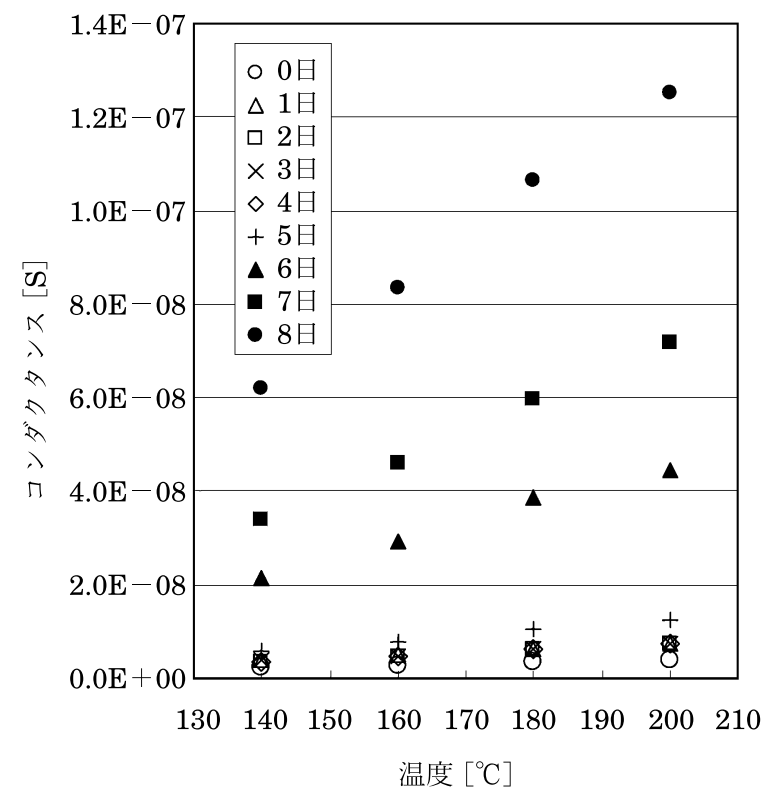

図 3 工場給食フライ油 F2 の測定温度とコンダクタンスとの関係

ンスの温度依存性が大きくなることを示している.

\section{2. フライ油の比誘電率およびコンダクタンスと劣化指}

\section{標との関係}

使用日数が異なるフライ油の劣化指標 (酸価, 重合物量, 色度）と比誘電率との関係を検討した。一例として病院給 食（H1）で使用したフライ油の測定結果を図 4 に示した。 フライ油の劣化度が増加するに従い比誘電率も増加した。 このようなフライ油の劣化度と比誘電率との関係は既往の 研究 ${ }^{10) 11)}$ においても同様に報告されている.

使用日数が異なるフライ油の劣化指標 (酸価, 重合物量, 色度）とコンダクタンスとの関係を検討した。一例として 学校給食（S1）で使用したフライ油の測定結果を図 5 に示 した. 比誘電率と同様にフライ油の劣化度が増加するに従 い, コンダクタンスも増加する傾向を示した。 また， フラ イ油の劣化度とコンダクタンスとの間には明瞭な相関関係 が認められた。

図 5 では, フライ油の酸価の増加に伴い, コンダクタン スが増加している．フライ油の劣化では, 加水分解により 遊離脂肪酸量が増加する。酸価の測定では, この遊離脂肪 酸を定量している. 従って, 図 5 における酸価の増加は遊 離脂肪酸量の増加を示していると考えられる.脂肪酸量の 増加に伴うコンダクタンス変化に関しては, 電気絶縁油に 脂肪酸の一種であるラウリン酸を種々の濃度で添加し, 絶 縁油の抵抗率 $\rho(\mathrm{m} / \mathrm{S})$ を測定した既往の研究があり, ラ ウリン酸の添加濃度の増加に伴い, 絶縁油の抵抗率は減少 することが報告されている ${ }^{12)}$. (2) 式より, 試料の抵抗率の 減少は，コンダクタンスの増加を意味することから，この 結果は, ラウリン酸などの脂肪酸の増加に伴い, 絶縁油の コンダクタンスが増加することを示しており, 本研究の結
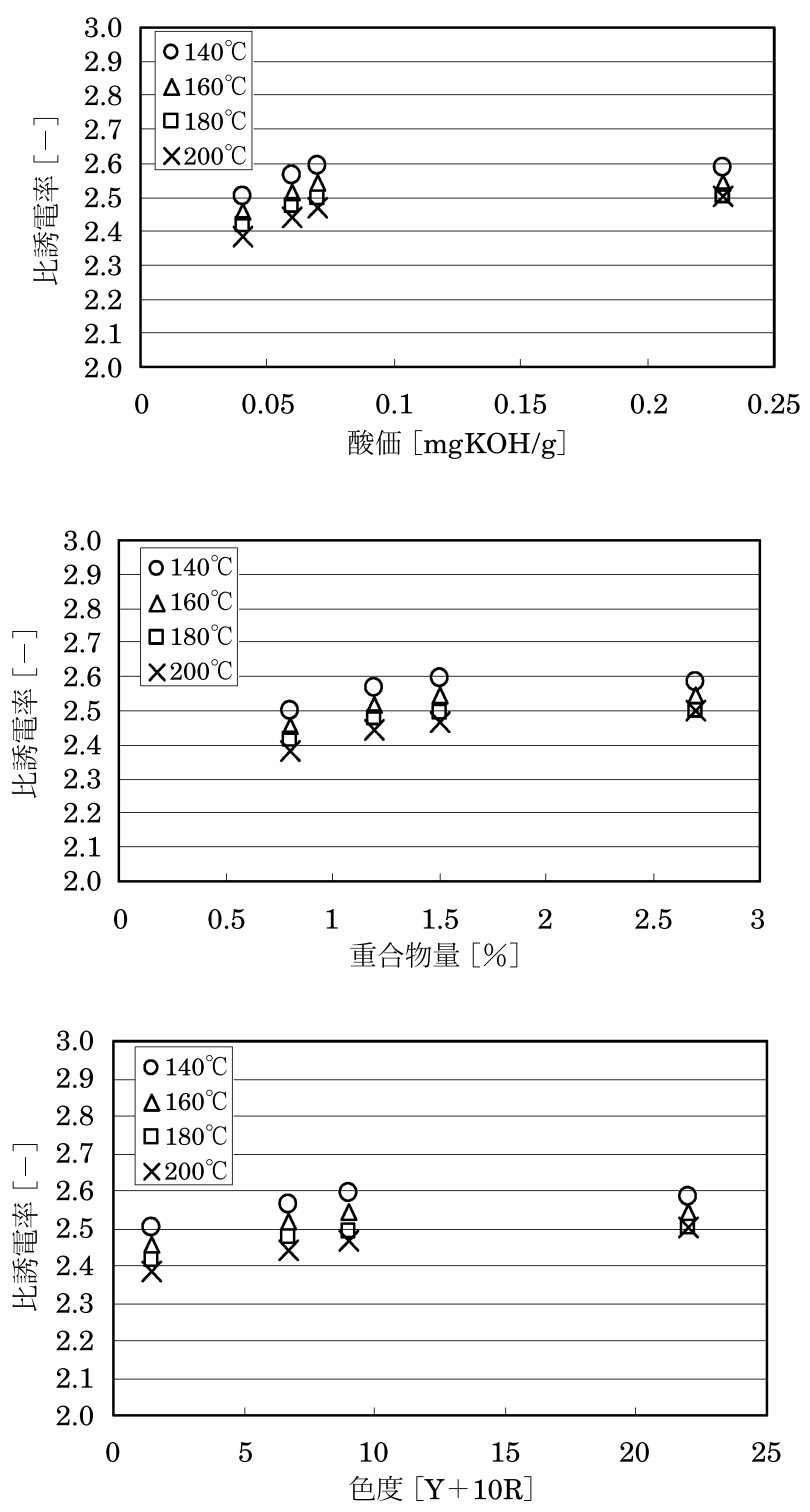

図 4 病院給食フライ油 H1 の劣化指標と比誘電率との関係

果とも一致する.

各温度に打けるフライ油の劣化度と電気的物性（比誘電 率，コンダクタンス）との間の相関係数（r）を表 2 に示し た. 比誘電率とコンダクタンスの相関係数を比較した場 合，全体的な傾向として，コンダクタンスは比誘電率より 屯高い相関を示している．この結果は，フライ油の劣化に 伴う化学的な变化とコンダクタンスとの関係を明確にする ことにより，コンダクタンス測定によるフライ油の劣化度 の定量的な計測の可能性を示している.

\section{3. コンダクタンスの温度依存性を利用したフライ油の 劣化度計測}

使用日数が異なるフライ油のコンダクタンスを 140 , 160，180，200 $\mathrm{C}$ で測定した結果（図 3) を見ると，フライ 油の使用日数が増加するに従い直線の傾きが大きくなって いることがわかる。ささらに表 1 より，フライ油の使用日数 

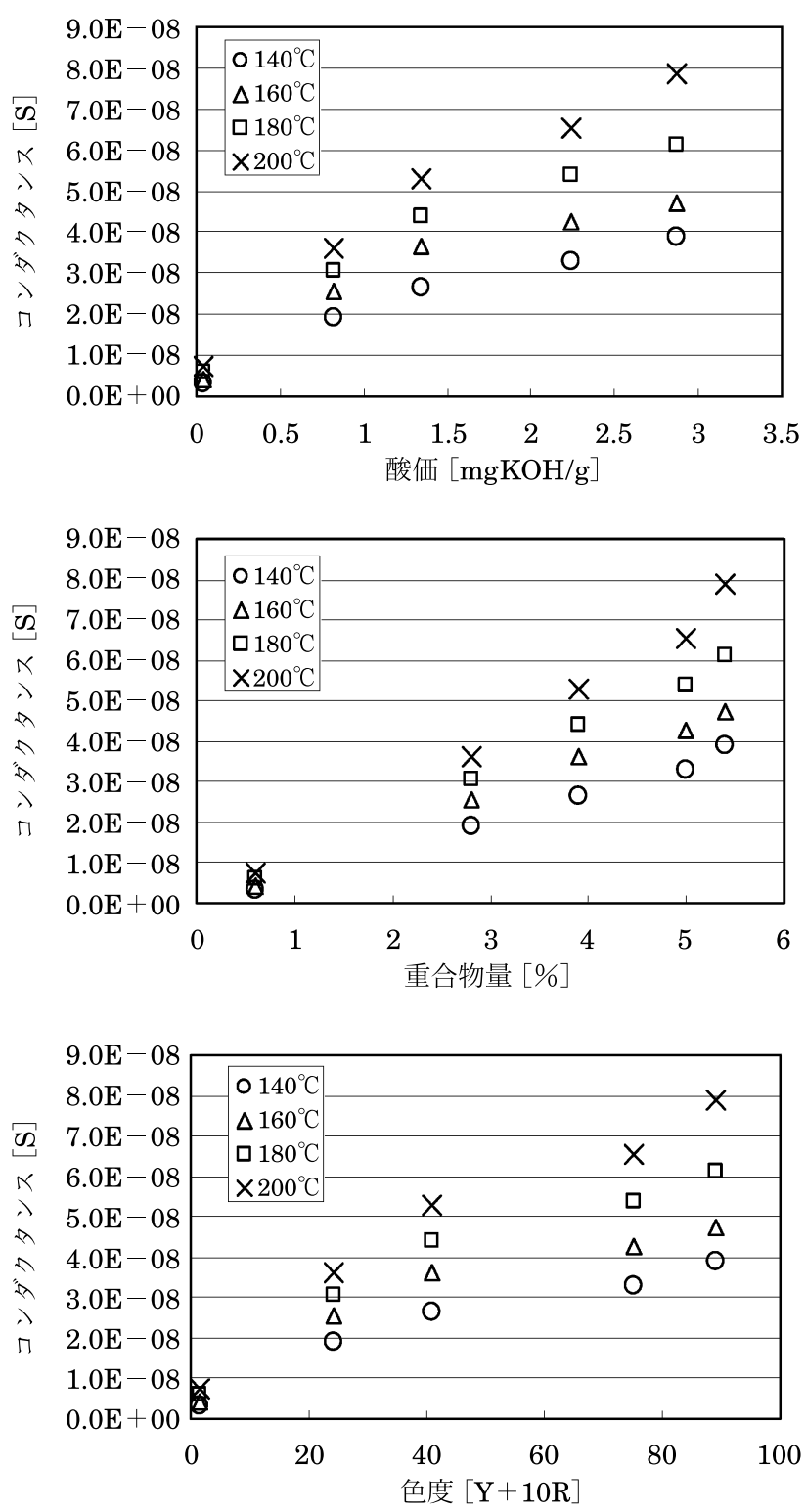

図 5 学校給食フライ油 S1 の劣化指標とコンダクタンスとの関係

の増加に伴い, 酸価, 重合物量, 色度と屯増加しているこ とから，フライ油の劣化度とコンダクタンスの温度依存性 との間には密接な関係があると考えられる。そこで，それ ぞれのフライ油について, コンダクタンスの温度依存性の 傾き $(\mathrm{dG} / \mathrm{dT}$ ) を求め, 劣化指標と比較し図 6 9 亿示し た。酸価, 重合物量, 色度ともコンダクタンスの温度依存 性の傾きとの間に良好な相関関係があることが分かる。

コンダクタンスの温度依存性の傾き $(\mathrm{dG} / \mathrm{dT})$ 之酸価之 の相関係数は学校給食フライ油 (S1) で 0.985, 病院給食フ ライ油（H1）および工場給食フライ油（F1，F2）で 0.998 であった. 同様に, $\mathrm{dG} / \mathrm{dT}$ と重合物量との相関係数は学校 給食フライ油（S1）で 0.988 , 病院給食フライ油（H1）で 0.975 , 工場給食フライ油 (F1) で 0.989 , 工場給食フライ油 （F2）で 0.980 であった. さらに, $\mathrm{dG} / \mathrm{dT}$ と色度との相関
表 2 各温度におけるフライ油の劣化指標と電気的物性との 間の相関係数 $(\mathbf{r})$

(a) 学校給食で使用したフライ油（S1）の相関係数

\begin{tabular}{ccccccc}
\hline \hline 温度 & (1) & (2) & (3) & (4) & (5) & (6) \\
\hline $140^{\circ} \mathrm{C}$ & 0.869 & 0.958 & 0.862 & 0.965 & 0.973 & 0.997 \\
$160^{\circ} \mathrm{C}$ & 0.862 & 0.954 & 0.854 & 0.940 & 0.946 & 0.996 \\
$180^{\circ} \mathrm{C}$ & 0.921 & 0.984 & 0.915 & 0.961 & 0.967 & 0.999 \\
$200^{\circ} \mathrm{C}$ & 0.975 & 0.991 & 0.966 & 0.971 & 0.978 & 0.994 \\
\hline
\end{tabular}

（b）病院給食で使用したフライ油（H1）の相関係数

\begin{tabular}{ccccccc}
\hline \hline 温度 & (1) & (2) & (3) & (4) & (5) & (6) \\
\hline $140^{\circ} \mathrm{C}$ & 0.517 & 0.685 & 0.695 & 0.952 & 0.978 & 0.987 \\
$160^{\circ} \mathrm{C}$ & 0.568 & 0.728 & 0.737 & 0.978 & 0.988 & 0.994 \\
$180^{\circ} \mathrm{C}$ & 0.631 & 0.776 & 0.788 & 0.987 & 0.979 & 0.985 \\
$200^{\circ} \mathrm{C}$ & 0.805 & 0.911 & 0.917 & 0.992 & 0.986 & 0.989 \\
\hline
\end{tabular}

（c）工場給食で使用したフライ油（F1）の相関係数

\begin{tabular}{ccccccc}
\hline \hline 温度 & (1) & (2) & (3) & (4) & (5) & (6) \\
\hline $140^{\circ} \mathrm{C}$ & 0.217 & 0.299 & 0.217 & 0.991 & 0.969 & 0.991 \\
$160^{\circ} \mathrm{C}$ & 0.399 & 0.472 & 0.400 & 0.991 & 0.970 & 0.991 \\
$180^{\circ} \mathrm{C}$ & 0.650 & 0.709 & 0.650 & 0.997 & 0.982 & 0.997 \\
$200^{\circ} \mathrm{C}$ & 0.804 & 0.846 & 0.805 & 0.998 & 0.986 & 0.998 \\
\hline
\end{tabular}

（d）工場給食で使用したフライ油（F2）の相関係数

\begin{tabular}{ccccccc}
\hline \hline 温度 & (1) & (2) & (3) & (4) & (5) & (6) \\
\hline $140^{\circ} \mathrm{C}$ & 0.655 & 0.604 & 0.624 & 0.998 & 0.979 & 0.996 \\
$160^{\circ} \mathrm{C}$ & 0.756 & 0.709 & 0.726 & 0.998 & 0.979 & 0.997 \\
$180^{\circ} \mathrm{C}$ & 0.791 & 0.755 & 0.808 & 0.998 & 0.980 & 0.997 \\
$200^{\circ} \mathrm{C}$ & 0.879 & 0.842 & 0.858 & 0.998 & 0.980 & 0.998 \\
\hline
\end{tabular}

(1) 酸価之誘電率, (2)重合物量之誘電率, (3) 色度と誘電率 (4) 酸価とコンダクタンス, (5)重合物量とコンダクタンス, (6)色度とコンダクタンス

係数は学校給食フライ油 $(\mathrm{S} 1)$ で 0.978 , 病院給食フライ油 (H1) で 0.976, 工場給食フライ油 (F1) で 0.998, 工場給食 フライ油（F2）で 0.999 であった. 以上の結果より, 酸価, 重合物量, 色度とも $\mathrm{dG} / \mathrm{d} \mathrm{T}$ との間には良好な相関関係が あることが明らかとなった。

フライ油が劣化する際に生成する物質（分解生成物，重 合物，遊離脂肪酸など）を総称して極性化合物という。極 性化合物は, 油脂の電気的な性質 (導電率などの絶縁性能) に大きく影響することが知られている。例えば，電気絶縁 用鉱物油を分別蒸留し，平均分子量の異なる絶縁油の導電 率を測定した既往の研究では, 導電率の温度依存性の傾き は分子量が大きくなるに従って大きくなることが報告 ${ }^{13}$ されている. (2)式より, 試料の導電率の増加は, コンダク タンスの増加を意味することから，これらの結果を解釈す ると, コンダクタンスの温度依存性の傾きの増加はフライ 油の分子量の増加, すなわち, 重合物の増加を示している と考えられる。 

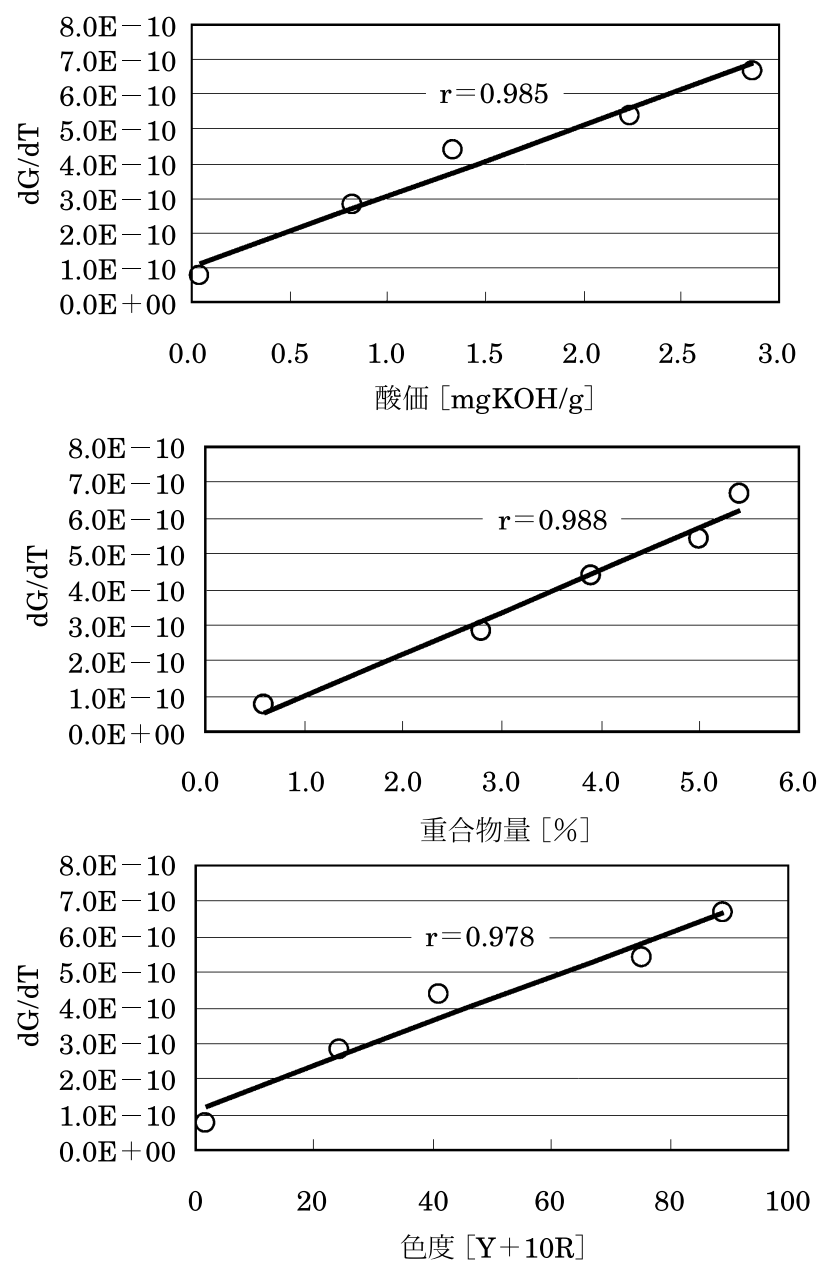

図 6 学校給食フライ油 S1 の劣化指標とコンダクタンスの 温度依存性の傾きとの関係

以上の結果より，コンダクタンスの温度依存性を利用す ることにより, フライ油の劣化度を容易に把握できること が明らかとなった。フライヤー内のフライ油の劣化度を連 続的に計測する場合には, 次のような方法が考えられる. すなわち，フライ油の温度とコンダクタンスを連続的に測 定できるように，電極板をフライヤー内に設置する. フラ イ油の温度設定の変更時にコンダクタンスの变化を計測す る。または，揚げだねの投入により起こるフライ油の温度 変化に伴うコンダクタンスの変化を計測する.これらの測 定值を用いて，コンダクタンスの温度依存性の傾き（dG/ $\mathrm{dT}$ ）を求めることにより, フライ油の劣化度を把握するこ とが可能となる。この方法では, フライ油の温度とコンダ クタンスの測定により, 比較的容易に酸価, 重合物量, 色 度が把握できるため, フライ油の品質管理には有効な方法 であると考えられる。

要 約

本研究では, 電気的物性 (比誘電率, コンダクタンス) と複数の劣化指標（酸価, 重合物量, 色度) との関係につ
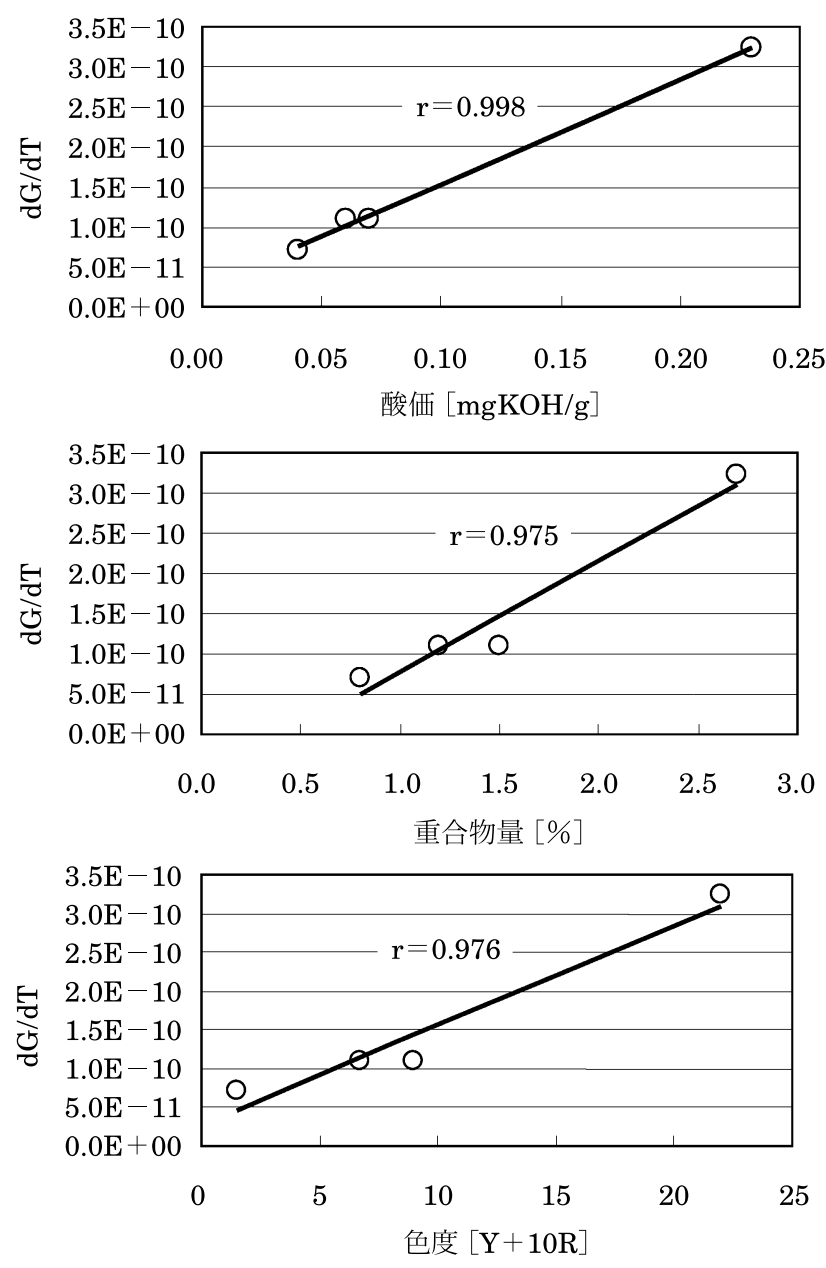

図 7 病院給食フライ油 H1 の劣化指標とコンダクタンスの 温度依存性の傾きとの関係

いて検討を行った。実験試料には，フライ食品の製造現場 において採取したフライ油を使用し，フライ油の電気的物 性および劣化指標を測定した。実験の結果，以下のことが 明らかとなった。

(1) フライ油の劣化度が増加するに従い比誘電率および コンダクタンスは増加する傾向を示した．特に，フライ油 の劣化度とコンダクタンスとの間には明瞭な相関関係が認 められた。

(2) フライ油のコンダクタンスの温度依存性の傾き $(\mathrm{dG} / \mathrm{dT})$ と劣化度との関係を検討したところ, 酸価, 重合 物量, 色度とも $\mathrm{dG} / \mathrm{dT}$ との間に極めて良好な相関関係が 認められた。

（3）以上の結果より，コンダクタンスの温度依存性を利 用することにより，フライ油の劣化度を容易に把握できる 可能性が示唆された.

本研究を遂行するにあたり, フライ油のサンプリングに ご協力頂きました，（有）クスノキ厨房の楠信行氏に深く感 謝申し上げます。また, 酸価・重合物量・色度の測定にご 

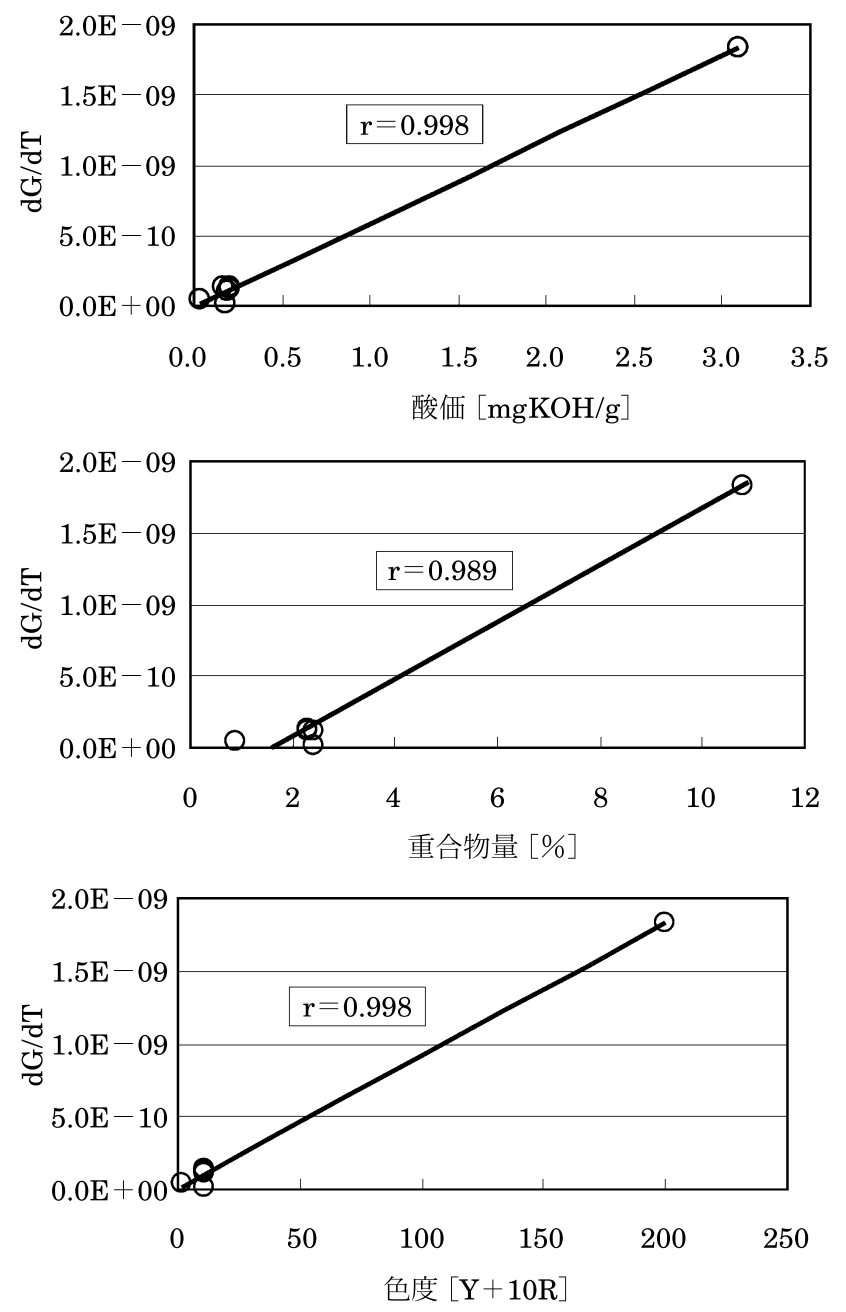

図 8 工場給食フライ油 F1 の劣化指標とコンダクタンスの 温度依存性の傾きとの関係

協力頂きました, 日清オイリオグループ(株) に深く感謝申 し上げます。

\section{文献}

1）太田静行, 揚げあのに関する諸問題, 油化学, 12，436-450 (1963).

2）調理科学研究会, 「調理科学」, (光生館, 東京), p. 76 (1984).

3）井崎やえ子, 戸田和子, 藤原光雄, 揚物調理油脂の劣化に伴 う化学指標の变化について, 食衛誌, 18, 191-200 (1977).

4）淺川具美, 松下雪朗, 加熱による油脂の劣化の簡易測定法, 栄養と食糧, 29, 47-49 (1976).

5) Paradis, A.J. and Nawar, W.W., Evaluation of New Methods for the Assessment of Used Frying Oils. J. Food Sci., 46,449-451 (1981).

6）日本食品衛生協会, 「弁当・そうざいの衛生規範」，（日本食 品衛生協会, 東京), p. 20 (1979).

7）太田静行, 湯木悦二,「改討 フライ食品の理論と実際」，（幸
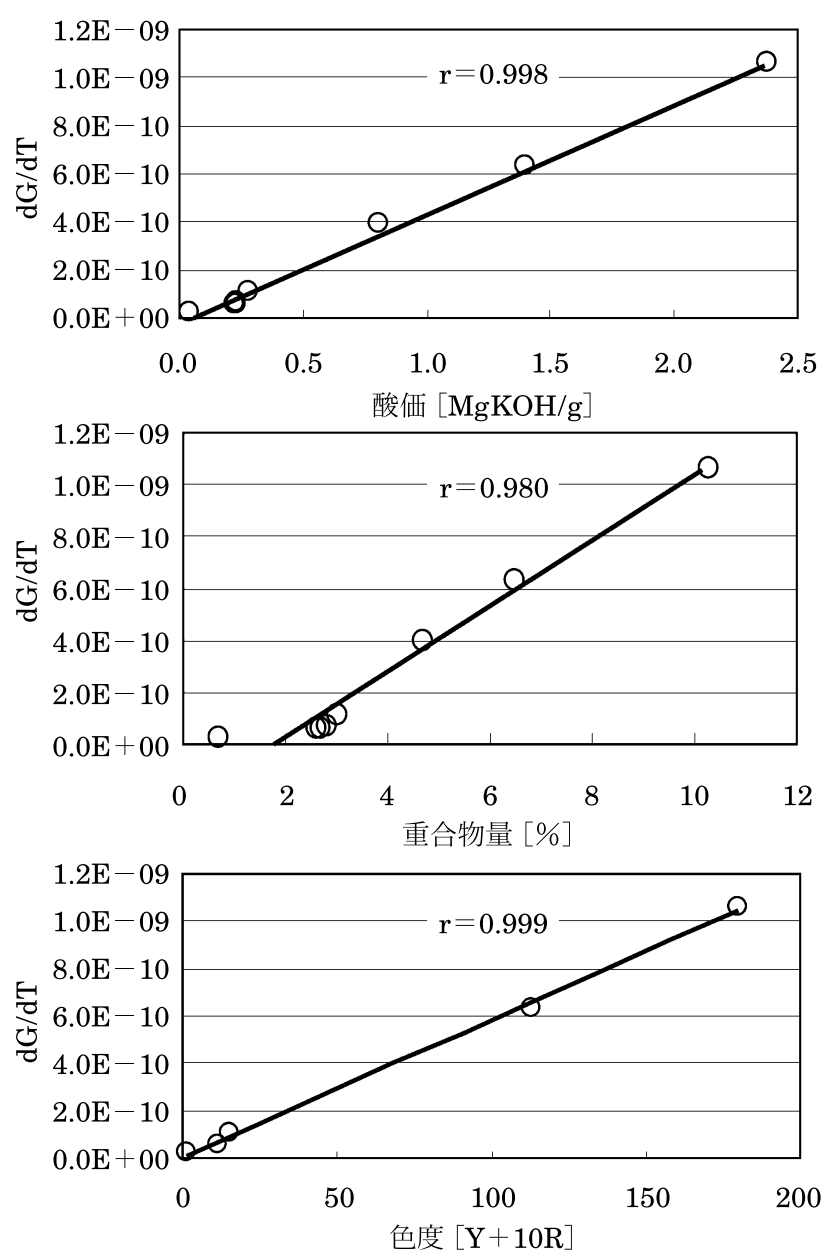

図 9 工場給食フライ油 F2 の劣化指標とコンダクタンスの 温度依存性の傾きとの関係

書房, 東京), pp. 139-140 (1994).

8) Tyagi, V.K. and Vasishtha, A.K., Changes in the characteristics and composition of oils during deep-fat frying. J. Amer. Oil Chem. Soc., 73, 499-506 (1996).

9）花井哲也, 「不均質構造之誘電率」, (吉岡書店, 京都), pp. 3-40 (2000).

10) Inoue, C., Hagura, Y., Ishikawa, M. and Suzuki, K., The dielectric property of soybean oil in deep-fat frying and the effect of frequency. J. Food Sci., 67, 1126-1129 (2002).

11) Fritch, C.W., Egberg, D.C. and Magnuson, J.S., Changes in dielectric constant as a measure of frying oil deterioration. J. Amer. Oil Chem. Soc., 56, 746-750 (1979).

12）電気絶縁材料便覧編集委員会編，「電気絶縁材料便覧」，（日 刊工業新聞社, 東京), p. 132 (1965).

13）宮本晃男, 土江基夫, 電気絶縁油におけるイオン伝導, 電気 学会論文誌 A, 98, 17-22 (1978).

(平成 18 年 1 月 4 日受付, 平成 18 年 6 月 10 日受理) 